\title{
Establishing an alternative method for the quantitative analysis of polychlorinated dibenzo-p-dioxins and polychlorinated dibenzofurans by comprehensive two dimensional gas chromatography-time-of-flight mass spectrometry for developing countries
}

\author{
Jayne de $\operatorname{Vos}^{\mathrm{a}_{*}}$, Peter Gorst-Allman ${ }^{\mathrm{b}}$, Egmont Rohwer ${ }^{\mathrm{c}}$ \\ ${ }^{a}$ National Metrology Institute of South Africa (NMISA), Private Bag X34, Lynnwood Ridge 0040, South Africa \\ ${ }^{\mathrm{b}}$ LECO Africa Pty Ltd., P O Box 1439, Kempton Park 1620, South Africa \\ ${ }^{c}$ Department of Chemistry, University of Pretoria, 0002, Pretoria, South Africa
}

Keywords:

US EPA Method 1613

Polychloro dibenzo-p-dioxins (PCDDs) and

polychloro dibenzofurans (PCDFs)

Environmental pollutants

Dioxins and dioxin quantitation

Persistent organic pollutants

\begin{abstract}
a b s t r a c t
Comprehensive Gas Chromatography-Time-of-Flight Mass Spectrometry (GC $\times$ GC-TOFMS) methodology has been refined for the analysis of polychlorinated dibenzo-p-dioxins (PCDDs) and polychlorinated dibenzofurans (PCDFs) in samples with different matrices. This is specifically for application in developing countries where access to gas chromatography-high resolution mass spectrometry (GC-HRMS) and highly skilled personnel is limited. The method, using an Rxi-5 Sil MS column in the first dimension $\left({ }^{1} \mathrm{D}\right)$ coupled with an Rtx-200 column in the second dimension $\left({ }^{2} \mathrm{D}\right)$, was used to quantify PCDDs and PCDFs in different environmental sample matrices. The results were compared with those obtained usingGC-HRMSandgoodagreementwasobserved.Thelimitofdetection(LOD)forthemethod(300fgon column for spiked soil samples) was determined using an Rxi-XLB $\left({ }^{1} \mathrm{D}\right)$ column coupled with an Rtx-200 column $\left({ }^{2} \mathrm{D}\right)$. Preliminary South African sample results are also discussed. Isomer specificity for different tetrachloro dibenzo-p-dioxins (TCDDs) and tetrachloro dibenzofurans (TCDFs) was investigated using a commercial standard. Adequate resolution was achieved. The method as described has great attraction for developing countries being both financially and operationally favourable.
\end{abstract}

\section{Introduction}

Polychlorinated dibenzo-p-dioxins (PCDDs) and polychlori-nated dibenzofurans (PCDFs) constitute two classes of structurally related chlorinated aromatic hydrocarbons that are both highly toxic and produced as by-products during a variety of chemical and combustion processes [1]. Due to their hydrophobic character and resistance to metabolic degradation these substances exist as complex congener mixtures in the environment.

South Africa has no established gas chromatography-high resolution mass spectrometry (GC-HRMS) facility for dioxin analysis [2]. This situation is not as a result of a lack of need; indeed in developing countries there is probably a greater need for strict control of effluent and waste disposal [3], but results from a shortage of finance available for the purchase of specialized scientific equipment, and also a shortage of skilled personnel needed for the optimum use and maintenance of such technology. The need for environmental monitoring is essential to ensure sustainable growth without exposing the

\footnotetext{
* Corresponding author. Tel.: +27 12841 4078; fax: +27 12841 2131. E-mail address: bjdevos@nmisa.org (J.de Vos).
}

population to dangerous toxins [4].

The lack of GC-HRMS facilities in South Africa (and other developing countries) mandates the development of an alternative solution that is affordable, easy to manage and aligned to the country's needs. The resultant analytical approach must be robust, must provide fast turnaround times and must accurately screen for many classes of environmental pollutants in a single analysis. This alternative methodologyisnot intendedas a replacement for exist-ing, acceptedtechnology forPCDDandPCDF analysis,butratherasa rapid screen,sothat only positivesamples canbesent for expensive GC-HRMS analysis in qualified overseas laboratories.

The National Metrology Institute of South Africa (NMISA), in collaboration with various institutions, launched the project towards a comprehensive screening method for multiple classes of persistent organic pollutants (POPs) in one run using Comprehensive Gas Chromatography-Time-of-Flight Mass Spectrometry $(\mathrm{GC} \times \mathrm{GC}-\mathrm{TOFMS})[5,6]$. There are numerous challenges that have to be overcome with this approach. Chief amongst these being the separation of the $\mathrm{PCDD} / \mathrm{F}$ congeners from each other and from matrix interference and the sensitivity considerations to allow accurate quantitative measurement down to 500 fg for $2,3,7,8$ - 
TCDD as required by US EPA Method 1613 [7]. The ultimate goal of this methodology would be a comprehensive screening method for multiple classes of POPs in one run [5,6] coupled with accurate quantitation of important pollutant classes. This paper focuses on PCDDs and PCDFs and describes the analysis of the seventeen priority PCDD/F congeners mandated by EPA Method 1613 [7].

$\mathrm{GC} \times \mathrm{GC}$-TOFMS was considered the preferred technique as it provides both the selectivity (added peak capacity of GCXGC) $[1,8]$ and the sensitivity (focusing effect of the modulator) [9] needed for this demanding environmental analysis. It is expected that the selectivity lost due to low resolution mass spectrometry (vs HRMS) will be offset by the higher selectivity of the extra gas chromatographic dimension. Moreover, as full range mass spectral data are always acquired (detailed full range mass spectral acquisition for selected classes of POPs is described in a previous paper [6]), it is not a target compound technique such as single ion monitoring (SIM), and is ideal for screening for multiple classes of environmental pollutants in a single analysis [1,10-14]. Retrospective data mining of archived data will be possible when future focus turns to new target compounds, e.g., the brominated dioxins.

This paper describes results on the analysis of PCDD/Fs aimed at establishing a dioxin capability for South Africa. More specifically, optimization of the column combinations and temperature programming are reported and results evaluated against sensitivity and isomer specificity guidelines of the US EPA Method 1613 [7].

\section{Experimental}

\subsubsection{Chemicals}

US EPA Method 1613 calibration and verification solutions (EPA1613CVS), labelled calibration solutions (EPA-1613LCS), internal standard spiking solution (EPA-1613ISS) and cleanup standard stock solution (EPA-1613CSS) were chosen for spiking and calibration purposes. These solutions were purchased from Wellington Laboratories (Guelph, Canada) and contained the seventeen native and corresponding mass-labelled PCDD/F congeners in nonane. The isomer specificity and window defining standard (EDF-4147 GC Retention Time Window Defining Solution and Isomer Specificity Test Standard) was purchased from Cambridge Isotope Laboratories (MA, USA).

All solvents (hexane, methylene chloride, nonane and isooctane) were high purity grade from Burdick and Jackson (Honeywell International Inc., USA). Sodium sulphate $\left(\mathrm{Na}_{2} \mathrm{SO}_{4}\right)$ anhydrous, sodium chloride $(\mathrm{NaCl})$ and potassium hydroxide $(\mathrm{KOH})$ were from Sigma-Aldrich (Chemie GmbH, Germany). Liquid nitrogen and chromatographic pure grade helium gas (99.999\%) were purchased from Air Products (Kempton Park, South Africa). The packing material used for sample extraction recovery was Chem Tube Hydromatrix ${ }^{\circledR}$ from Varian Inc. (supplied via SMM Instruments, South Africa). The consumables for the recovery determinations using the Total Rapid Preparation (TRP) system (Fluid Management Systems, Watertown, MA, USA) included a $3 \mathrm{~g}$ "in cell” cleanup column (packed with $\mathrm{Na}_{2} \mathrm{SO}_{4}$, and Hydromatrix ${ }^{\circledR}$ ) for pressurized liquid extraction. Further sample cleanup included high capacity PCB-free Silica (\#PCB HCDS), acid base neutral Silica (\#PCBS: ABN), Alumina (\#PCBA: BAS) and Carbon (\#PCBC: CCG).

\subsubsection{Sample preparation}

Sediment samples were provided by the Environmental Protection Agency (EPA) in Taiwan. Extraction, clean-up and GC-HRMS analysis of these samples were performed by the same laboratory. The sample extraction procedure for the PCDD/Fs follows the
US EPA Method1613 [7]. The samples were analysed using both GC-HRMS (according to US EPA Method 1613) and GC $\times$ GC-TOFMS (Table 1c, supporting information).

Soil and sediment samples were also taken from selected sites within South Africa. The soil and sediment samples were extracted and underwent clean-up procedures adapted from existing US EPA Methods (3545 [15]; 3620 C [16]; 3600 C [17] and 1613 [7]) at the North West University (NWU), Potchefstroom, South Africa.

The samples were transported and stored at $4{ }^{\circ} \mathrm{C}$, air-dried, homogenized and sieved $(0.5 \mathrm{~mm})$. After mixing $40 \mathrm{~g}$ of soil with an equal amount of $\mathrm{Na}_{2} \mathrm{SO}_{4}$ and spiking with $10 \mu \mathrm{l}$ of ${ }^{13} \mathrm{C}_{12}$ labelled internal standard $(100 \mathrm{ng} / \mathrm{ml}$, EPA-1613CSL), the samples were extracted with a mixture of high-purity hexane and dichloromethane (DCM) using accelerated solvent extraction (ASE). Prior to clean-up, the extracts were spiked with $10 \mu \mathrm{l}$ of EPA-1613CSS clean-up standard $\left({ }^{37} \mathrm{Cl}_{4}-2,3,7,8-\mathrm{TCDD}\right)$. The exact clean-up procedure depended on the target compound. All extracts underwent gel permeation chromatography (GPC) to remove all molecules outside the size range of the target compounds. After GPC the sample was evaporated to $0.5 \mathrm{ml}$, reconstituted to $1.5 \mathrm{ml}$ (iso-octane) and then split into separate portions $(0.5 \mathrm{ml})$ for three different clean-up procedures.

The dioxin clean-up procedure consisted of a concentrated sulphuric acid wash, followed by a $5 \% \mathrm{NaCl}$ wash ( $60 \mathrm{~min}$ ), a $\mathrm{KOH}$ wash (10-15 min) and lastly a second $5 \% \mathrm{NaCl}$ wash (60 min). Samples were filtered through pre-extracted glass wool covered with $\mathrm{Na}_{2} \mathrm{SO}_{4}$ to remove residual water and evaporated to $0.5 \mathrm{ml}$ in isooctane.

The recovery determinations were performed using the Total Rapid Preparation (TRP) system [11,18]. Two $10 \mathrm{~g}$ sterilized soil samples were spiked with $10 \mu$ l of ${ }^{13} C_{12}$ labelled internal standards $(100 \mathrm{ng} / \mathrm{ml})$ and extracted using the TRP Pressurized Liquid Extraction module [18], solvent evaporated using the Concentrator module, labelled clean-up standard $(10 \mu \mathrm{l})$ added (EPA-1613CSS) and clean-up using the TRP Power Prep module with final solvent evaporation to $0.5 \mathrm{ml}[18,19]$. The extraction and analytical method followed US EPA Method 1613 [7].

\subsection{3. $G C \times$ GC-TOFMS analysis}

The GC $\times$ GC-TOFMS system used in this study at the NMISA was a Pegasus 4D (LECO Corporation, St Joseph, MI, USA). The system has an Agilent 7890 GC equipped with an Agilent 7683B autosampler, a secondary oven and a dual stage modulator. Liquid nitrogen $\left(\mathrm{LN}_{2}\right)$ was used for the cold jets and synthetic air for the hot jets. The $\mathrm{LN}_{2}$ levels were maintained using an AMI Model 186 liquid level controller. One set of analyses was performed on the system at the EPA (Taiwan) laboratory using the Restek Rxi-5silms/Rtx-200 column combination (similar to column combination 2, Table 1 ). This system is identical to the system at the NMISA where the remainder of the analyses was performed.

Three specific GC column combinations were evaluated during this study. These columns included an Rtx-Dioxin 2/Rtx-PCB, an Rxi-5 Sil MS/Rtx-200 and an Rxi-XLB/Rtx-200 (Table 1a, supporting information). All the columns used were obtained from Restek (Bellefonte, PA, USA). Primary and secondary columns were connected using a press-tight connector.

The system was tuned on the 414 ion from the conventional perfluorotributylamine (PFTBA) mass calibrant. This is different from the standard tuning procedure and is an attempt to improve the signal intensity at the higher mass range [21]. All instrument functions and data processing were managed with the LECO ChromaTOF software (version 4.24). Manual review of all peak identifications and integrations was performed using this software. Library searching was performed using a PCDD/F user library compiled from the PCDD/F standards. 


\section{Results and discussion}

\begin{tabular}{|c|c|}
\hline First dimension column & Rxi-XLB $(30 \mathrm{~m} \times 0.25 \mathrm{~mm}$ id $\times 0.25 \mu \mathrm{m} \mathrm{df})$ \\
\hline Second dimension column & Rtx-200 $(2.0 \mathrm{~m} \times 0.18 \mathrm{~mm}$ id $\times 0.20 \mu \mathrm{m} \mathrm{df})$ \\
\hline Carrier gas & Helium \\
\hline Injection mode & Splitless \\
\hline Injection volume & $2 \mu l$ \\
\hline Solvent & Iso-octane \\
\hline Flow mode & Constant flow \\
\hline Flow rate & $1.0 \mathrm{ml} \mathrm{min}^{-1}$ \\
\hline Inlet purge time & $60 \mathrm{~s}$ \\
\hline Inlet purge flow & $20 \mathrm{ml} \mathrm{min}^{-1}$ \\
\hline Inlet total flow & $21 \mathrm{ml} \mathrm{min}^{-1}$ \\
\hline Inlet temperature & $250{ }^{\circ} \mathrm{C}$ \\
\hline Oven equilibration time & $0.5 \mathrm{~min}$ \\
\hline${ }^{1} \mathrm{D}$ column temperatures & 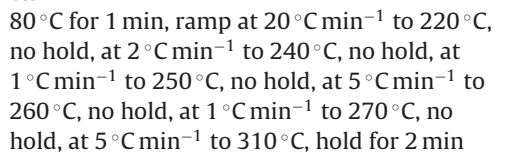 \\
\hline${ }^{2} \mathrm{D}$ column temperatures & $\begin{array}{l}100^{\circ} \mathrm{C} \text { for } 1 \mathrm{~min} \text {, ramp at } 20^{\circ} \mathrm{C} \mathrm{min}^{-1} \text { to } 240^{\circ} \mathrm{C} \text {, } \\
\text { no hold, at } 2^{\circ} \mathrm{C} \mathrm{min}^{-1} \text { to } 260^{\circ} \mathrm{C} \text {, no hold, at } \\
1^{\circ} \mathrm{C} \mathrm{min}-1 \text { to } 270^{\circ} \mathrm{C} \text {, no hold, at } 5^{\circ} \mathrm{C} \mathrm{min}^{-1} \text { to } \\
280^{\circ} \mathrm{C} \text {, no hold, at } 1^{\circ} \mathrm{C} \mathrm{min}^{-1} \text { to } 290^{\circ} \mathrm{C} \text {, no } \\
\text { hold, at } 5^{\circ} \mathrm{C} \mathrm{min}^{-1} \text { to } 330^{\circ} \mathrm{C} \text {, hold for } 2 \text { min }\end{array}$ \\
\hline Transfer line temperature & $270^{\circ} \mathrm{C}$ \\
\hline Modulator temperature offset & $30^{\circ} \mathrm{C}$ \\
\hline Modulation period & $4 \mathrm{~s}$ \\
\hline Hot pulse time & $1.0 \mathrm{~s}$ \\
\hline Cool time between stages & $1.0 \mathrm{~s}$ \\
\hline Acquisition delay & $600 s$ \\
\hline Start mass & $100 \mathrm{amu}$ \\
\hline End mass & $520 \mathrm{amu}$ \\
\hline Acquisition rate & 50 spectra s $^{-1}$ \\
\hline Detector voltage & $1950 \mathrm{~V}$ \\
\hline Electron energy & $-70 \mathrm{~V}$ \\
\hline Mass defect setting & $-40 \mathrm{mu} / 100 \mathrm{u}$ \\
\hline Ion source temperature & $250^{\circ} \mathrm{C}$ \\
\hline
\end{tabular}

The Rxi-5 Sil MS/Rtx-200 column combination was selected for quantitation of the Taiwan results and the Rxi-XLB/Rtx-200 column combination was selected for final quantitation of the South African spikes and sediment sample results (see Section 3). All instrument parameters are shown in Table 1 and in the supporting information (Table $1 \mathrm{a}-\mathrm{d}$ ).

\subsection{Selectivity using different column combinations}

Selectivity starts with good chromatography. The choice of column combinations for comprehensive GC $\times$ GC-TOFMS has been detailed in the literature [11-20]. The first approach for dioxin analysis at the NMISA was based on the method by Hoh [21]. A $60 \mathrm{~m}$ Rtx-Dioxin2 column was used (Table 1a and b, supporting information) and the total run time for the analysis was longer than $60 \mathrm{~min}$. After analysis of the data, it was evident that considerable wrap-around of the dioxin compounds (hepta and octa) had occurred [22], as can be seen from Fig. 1. This could have an impact on quantitation as broader peaks have a detrimental effect on area determination at the low levels (500 fg for 2,3,7,8TCDD) stipulated in US EPA Method 1613 [7], and it is also possible that target compounds can wrap-around into areas of high matrix contamination.

This led to the decision to consider a $30 \mathrm{~m}$ column and to standardize on a conventional stationary phase such as a $5 \%$ diphenyldimethylsiloxane; a columns that most South African laboratories would have available. Thus the Rxi-5 Sil MS/Rtx-200 column combination (Table $1 \mathrm{a}$ and $\mathrm{c}$, supporting information) was initially selected to optimize the dioxin method using GC $\times$ GC-TOFMS. This column combination was also used at the EPA in Taiwan by one of the authors to analyse the fly ash and sediment samples by GC $\times$ GC-TOFMS for comparison with GC-HRMS data from the same institution. Good separation of the seventeen priority PCDD/F congeners was achieved (Fig. 2) with this combination, and the method was used to calculate the results detailed in Table 2. Since the total toxic equivalency (TEQ) value is combined from the individual toxic equivalency factors (TEFs) for all seventeen PCDD/F congeners [23], the contribution of each congener to the total value has to be established and it is therefore essential to separate the seventeen PCDD/F congeners from each other, especially the seven hexachlorodibenzo-p-dioxins and furans (HxCDD/Fs). By using the excellent efficiency, inertness, low bleed and high thermal stability of the low polarity Restek Rxi-XLB column phase in the first dimension coupled with the mid-polarity phase Rtx-200 (cross-bond trifluoropropylmethyl polysiloxane) in the second dimension, this separation was achieved (see Fig. 3). This provided more confidence

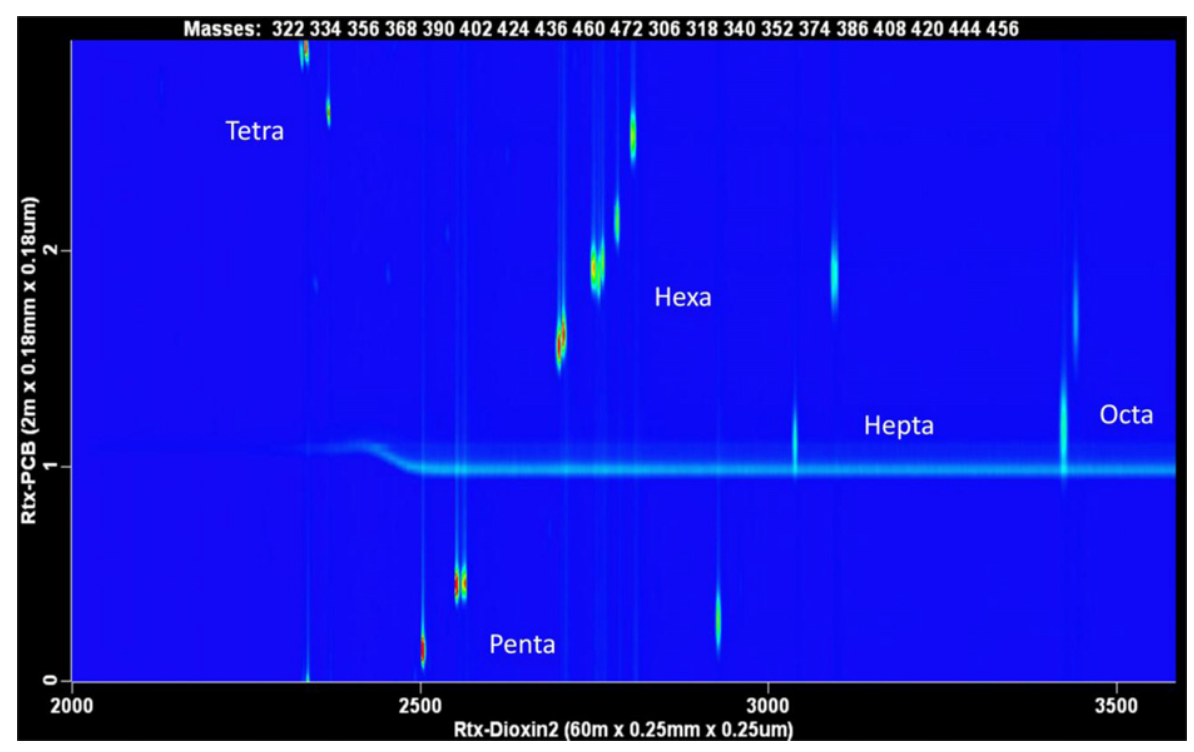

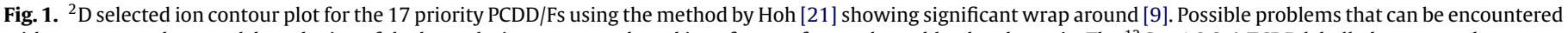

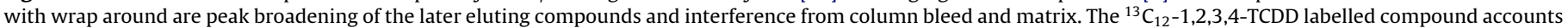
for the 18 peaks that are visible. 


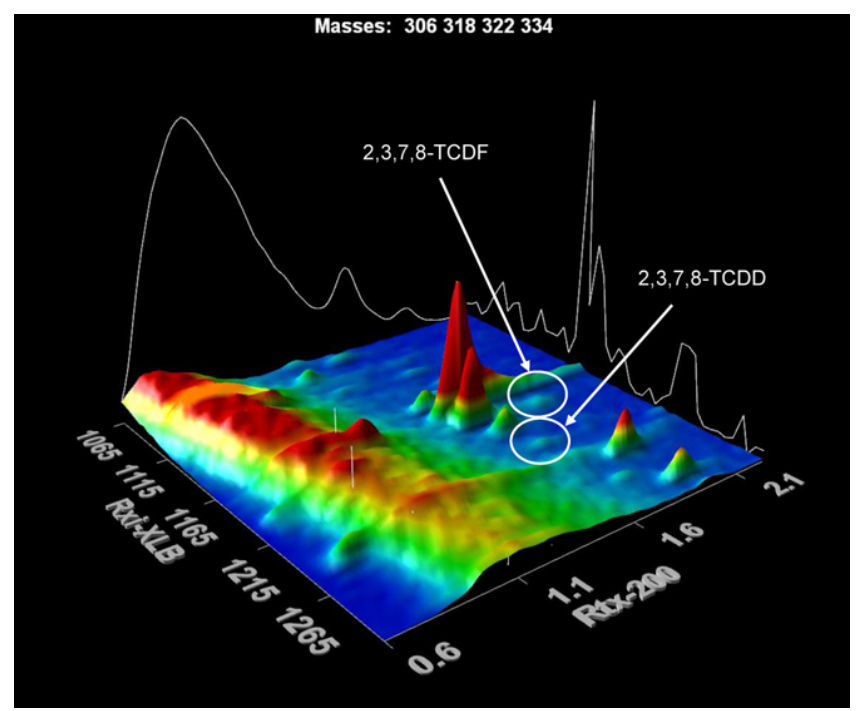

Fig. 4. Surface plot showing the position of the 2,3,7,8-TCDF and 2,3,7,8-TCDD in the presence of matrix interference. Fig. 3 has shown the separation of standards and the position of the TCDD/F isomers in the chromatographic space. In this chromatogram it is evident that the TCDD/F peaks would not be detected in a ${ }^{1} \mathrm{D}$ separation; the peaks would be buried under the matrix interference. The ${ }^{2} \mathrm{D}$ separation clearly removes the target analytes from the matrix interference, allowing for accurate quantitation.

In terms of toxicity $[1,3,4,23,25,26]$, and US EPA Method 1613 [7] requirements, the crucial low level compound under evaluation is the 2,3,7,8-TCDD. Using the EPA-1613CVS standard calibration set described in Section $2(0.5-200 \mathrm{pg} / \mu \mathrm{l})$, a calibration curve was constructed for the seventeen components of the standard set. For the 2,3,7,8-TCDD the calibration curve obtained was linear with a correlation coefficient of 0.99972 (slope and intercept: $+0.0102161 x+0.000851118$ ) and an average response factor (aveRF) of 1.061. The ability of the method to reach the required low level quantitation was then further investigated.

The low level standard (CS1) which contains 2,3,7,8-TCDD at $0.5 \mathrm{pg} / \mu \mathrm{l}$ was used to determine the LOD possible for this compound. Using the method described in EPA Method 1613, the signal/noise (S/N) ratio for the ion of $m / z 322$ for 2,3,7,8-TCDD was calculated [24] as 20 (EPA Method 1613 requires this ratio to be $>10$ [7]). This confirms that the method can reach the LOD required by EPA Method 1613. The relevant chromatographic peaks used for the quantitation of the 2,3,7,8-TCDD standard at a concentration of $0.5 \mathrm{pg} / \mu \mathrm{l}$, together with the corresponding labelled standard at a concentration of $100 \mathrm{pg} / \mu \mathrm{l}$ are shown in Fig. 5 (Fig. 5a and b, supporting information). Even for the lowest level standard $(0.5 \mathrm{pg} / \mu \mathrm{l})$ the chromatographic peak for the ion at 322 atomic mass units (amu) was easily discernible and could be accurately quantified. The mass spectra obtained for the 2,3,7,8-TCDD/F are easily searched against a user library, with a similarity match of $77 \%$ for $500 \mathrm{pg}$ on column (Fig. $5 \mathrm{c}$ and d, supporting information).

To confirm that this LOD was attainable in soil samples, two $10 \mathrm{~g}$ sterilized soil samples were spiked with native dioxins at concentration levels of $500 \mathrm{pg}$ (sample 1) and $2000 \mathrm{pg}$ (sample 2) for 2,3,7,8-TCDD. After adding labelled material, extraction (ASE), clean-up (GPC) and concentration (NWU, Potchefstroom, South Africa, see acknowledgements), it was possible to calculate LODs for 2,3,7,8-TCDD of $322 \mathrm{fg}$ for sample 1 and $353 \mathrm{fg}$ for sample 2 . These calculations were made by determining the $\mathrm{S} / \mathrm{N}$ for the ion of $\mathrm{m} / \mathrm{z}$ 322 and extrapolating linearly to a $\mathrm{S} / \mathrm{N}$ of 3:1. These results are consistent with the LOD determination using the low level standard detailed above, and provide assurance that the method has the sensitivity for low level dioxin determination. Quantitation was 


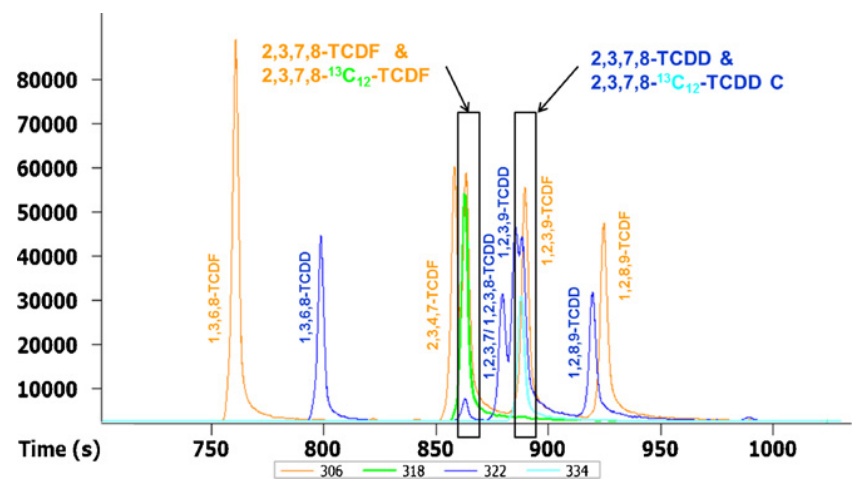

Fig. 7. Isomer specificity ${ }^{1} \mathrm{D}$ separation using the same Rxi-5 Sil MS column. A multi-step temperature program was used (Table 1). There is not much difference in chromatographic separation (compared with Fig. 6), but it does confirm compliance with the US EPA Method 1613 requirements for using a DB-5 equivalent phase.

Moreover, the overlap of compounds not necessary for quantitation by EPA Method 1613 is of no importance for final TEQ determination.

The separation in ${ }^{2} \mathrm{D}$ for the Rxi-5 Sil MS/Rtx-200 and RxiXLB/Rtx-200 column combinations can be seen in Figs. 9 and 10. From the chromatograms ( ${ }^{2} \mathrm{D}$ contour plots) it is evident that the $2,3,7,8-\mathrm{TCDF} / 2,3,7,8-\left[{ }^{13} \mathrm{C}_{12}\right]$-TCDF and the $2,3,7,8-\mathrm{TCDD} / 2,3,7,8$ $\left[{ }^{13} C_{12}\right]$-TCDD separation with the XLB phase has been achieved with no overlapping interference from the other TCDD/F isomers present.

\subsection{Sample analysis}

The analysis of dioxins based on standards is necessary in order to familiarize the laboratory analyst with these toxic compounds and their intrinsic chromatographic properties. Method development and optimization has to be followed by method validation. The laboratory of the EPA in Taiwan is equipped with both GC-HRMS and GC $\times$ GC-TOFMS systems and it was possible to compare the results provided from a set of samples analysed by the standard GC-HRMS method with the ones we obtained

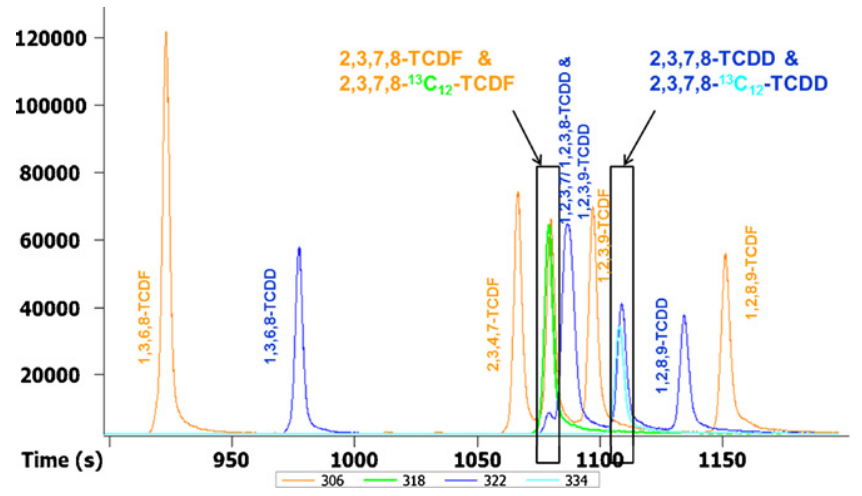

Fig. 8. Isomer specificity ${ }^{1} \mathrm{D}$ separation on the Rxi-XLB column using the multistep temperature program (Table 1 ). There is definite improvement with the phase change between the Rxi-5 Sil MS and XLB columns. The 2,3,7,8-TCDF/2,3,7,8-[ $\left.{ }^{13} \mathrm{C}_{12}\right]-$ TCDF and the $2,3,7,8-\mathrm{TCDD} / 2,3,7,8-\left[{ }^{13} \mathrm{C}_{12}\right]$-TCDD isomers are well separated from the other isomers.

using their GC $\times$ GC-TOFMS. Table 2 shows an example of the results for two sediment samples, one fly ash sample and one check standard. There is good agreement between the GC-HRMS and GC $\times$ GC-TOFMS data sets, indicating that the GC $\times$ GC-TOFMS method is capable of handling this complex dioxin analysis for environmental samples.

With the TRP system, it was possible to establish recovery data for two blank samples spiked at different concentration levels. The results shown in Table 4 provided a set of data that corroborated the calculated versus actual results. The toxicity of the various compounds is defined in terms of the toxic equivalency factor (TEF) [23]. The 2,3,7,8-TCDD is assigned a value of one, and the other dioxin and furan compounds are compared to it. Thus 2,3,7,8-TCDF is rated one tenth as toxic as $2,3,7,8-T C D D$ [26]. When reporting the results, these values are then added together to give a total toxicity equivalent for the seventeen dioxins and furans. As can be seen in Table 4, the calculated value obtained was $280 \mathrm{ng} \mathrm{TEQ} / \mathrm{kg}$ and the actual analytical result obtained was $290 \mathrm{ng} \mathrm{TEQ} / \mathrm{kg}$, with recoveries between 70 and $110 \%$. These results confirm that the GC $\times$ GC-TOFMS method meets the US EPA 1613 criteria.
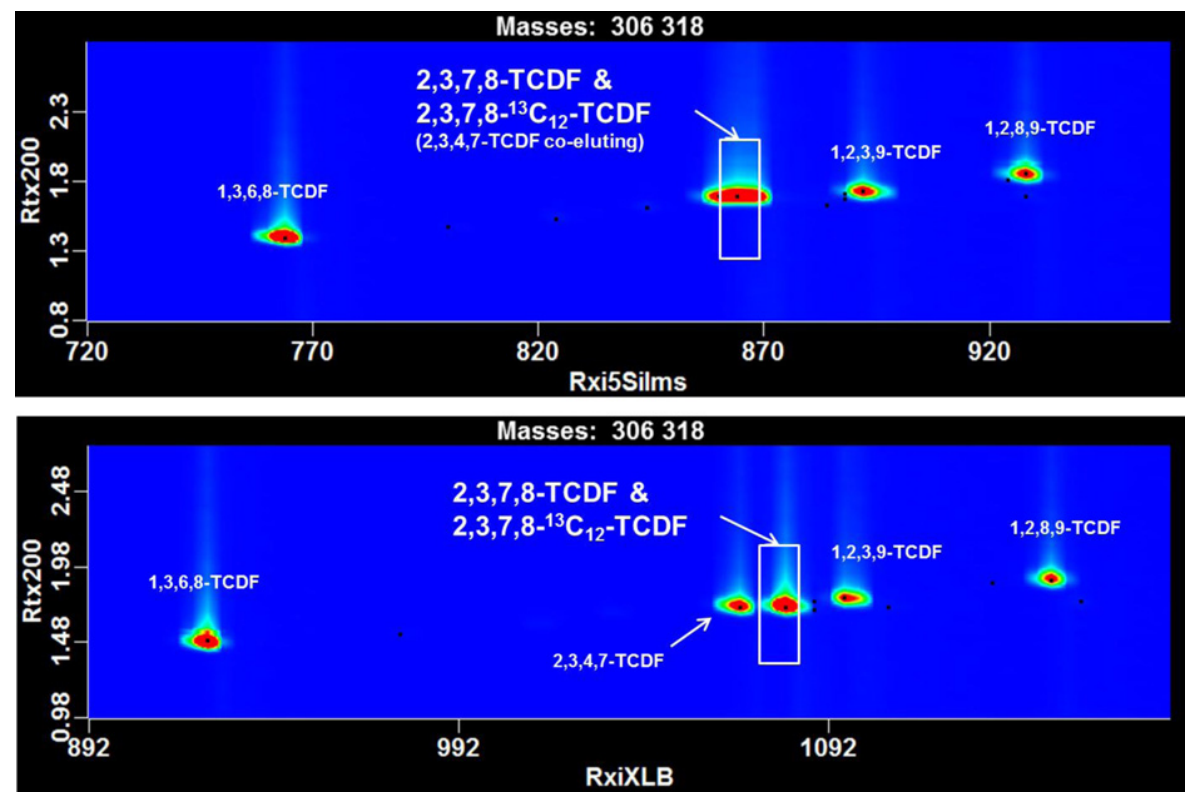

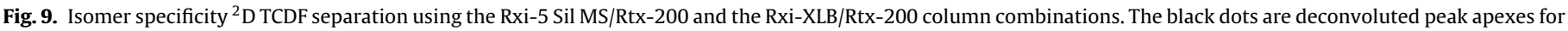

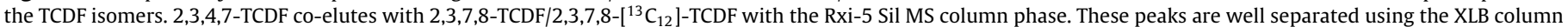
phase. 

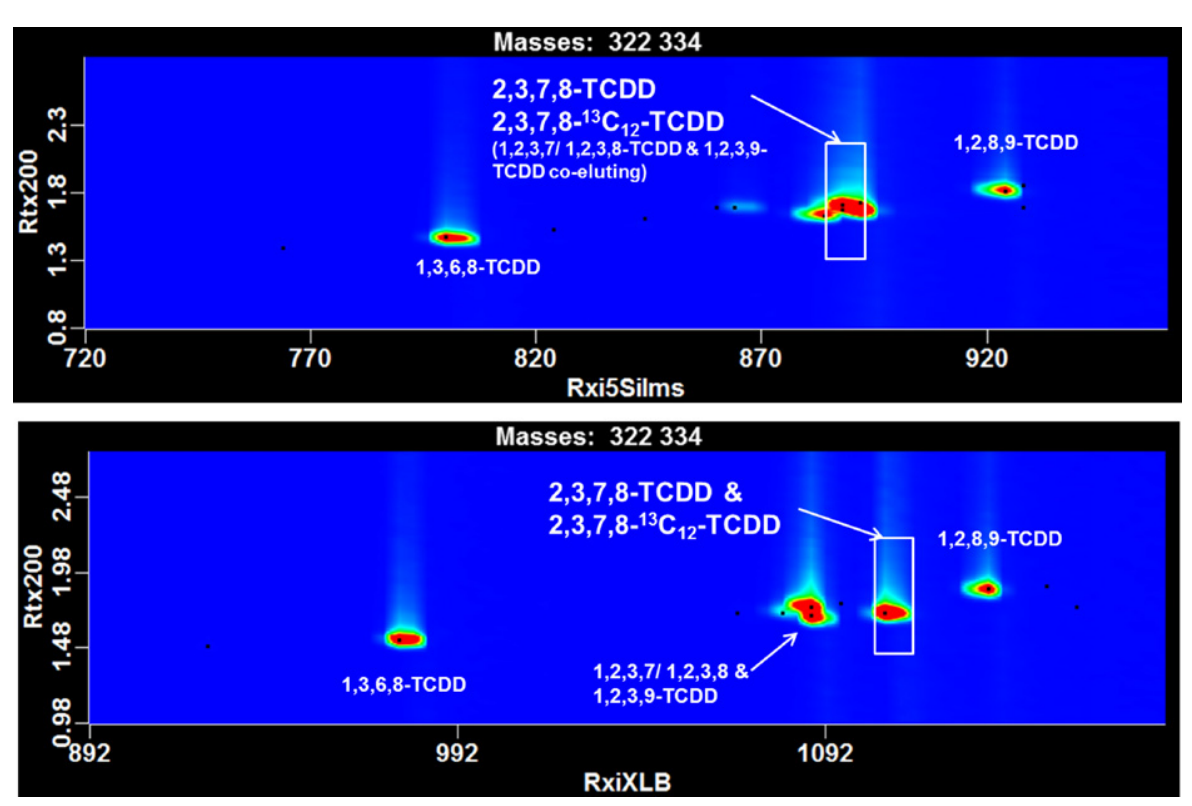

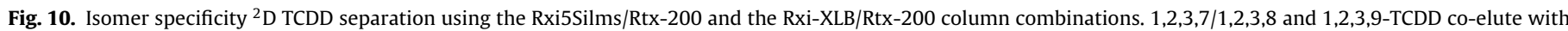

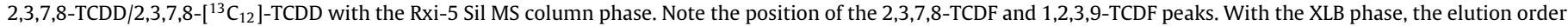

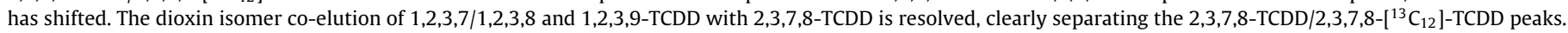
$1,2,3,7 / 1,2,3,8-T C D D$ and $1,2,3,9-T C D D$ are resolved in ${ }^{2} \mathrm{D}$.

Table 4

South African GC $\times$ GC-TOFMS soil spike recovery results (Rxi-XLB/Rtx-200 column combination).

\begin{tabular}{|c|c|c|c|c|c|c|c|}
\hline Compound & ${ }^{1} \mathrm{D} \mathrm{RT}$ & ${ }^{2} \mathrm{D} \mathrm{RT}$ & ${ }^{\mathrm{a}} \mathrm{TOF}$ & ${ }^{\mathrm{b}}$ Spike & ${ }^{\mathrm{c}} \mathrm{TOF}$ TEF & ${ }^{\mathrm{d}}$ Spike TEF & \% Recovery \\
\hline $2,3,7,8-\mathrm{TCDD}$ & 1116 & 1.76 & 29 & 25 & 29 & 25 & 114 \\
\hline 1,2,3,7,8-PeCDD & 1436 & 2.12 & 124 & 127 & 124 & 127 & 98 \\
\hline $1,2,3,4,7,8-\mathrm{HxCDD}$ & 1812 & 2.50 & 108 & 127 & 11 & 13 & 85 \\
\hline $1,2,3,6,7,8-\mathrm{HxCDD}$ & 1824 & 2.52 & 128 & 127 & 13 & 13 & 100 \\
\hline $1,2,3,7,8,9-\mathrm{HxCDD}$ & 1848 & 2.62 & 90 & 127 & 10 & 12 & 70 \\
\hline $1,2,3,4,6,7,8-\mathrm{HpCDD}$ & 2216 & 2.90 & 129 & 127 & 1.3 & 1.3 & 102 \\
\hline OCDD & 2616 & 3.16 & 195 & 254 & 0.1 & 0.1 & 77 \\
\hline $2,3,7,8-\mathrm{TCDF}$ & 1088 & 1.76 & 26 & 25 & 2.5 & 2.5 & 101 \\
\hline $1,2,3,7,8-\mathrm{PeCDF}$ & 1332 & 2.02 & 92 & 127 & 2.7 & 3.8 & 72 \\
\hline $2,3,4,7,8-\mathrm{PeCDF}$ & 1420 & 2.16 & 103 & 127 & 30 & 40 & 81 \\
\hline $1,2,3,4,7,8-\mathrm{HxCDF}$ & 1720 & 2.34 & 118 & 127 & 12 & 13 & 93 \\
\hline $1,2,3,6,7,8-\mathrm{HxCDF}$ & 1732 & 2.38 & 131 & 127 & 13 & 13 & 103 \\
\hline $2,3,4,6,7,8-\mathrm{HxCDF}$ & 1800 & 2.62 & 140 & 127 & 14 & 13 & 110 \\
\hline $1,2,3,7,8,9-\mathrm{HxCDF}$ & 1888 & 2.68 & 140 & 127 & 14 & 13 & 110 \\
\hline $1,2,3,4,6,7,8-\mathrm{HpCDF}$ & 2064 & 2.72 & 120 & 127 & 1.2 & 1.3 & 95 \\
\hline $1,2,3,4,7,8,9-\mathrm{HpCDF}$ & 2296 & 2.92 & 95 & 127 & 1.0 & 1.3 & 75 \\
\hline OCDF & 2636 & 3.08 & 176 & 254 & 0.1 & 0.1 & 69 \\
\hline TOTAL PCDD/Fs & & & & & 280 & 290 & \\
\hline
\end{tabular}

2005 World Health Organization (WHO) Toxicity Equivalency Factor (TEF) values [23].

a TOF: GC $\times$ GC-TOFMS results $\left(\mathrm{ng} \mathrm{kg}^{-1}\right)$.

b Spike: calculated $\left(\mathrm{ng} \mathrm{kg}^{-1}\right)$.

c TOF TEF: GC $\times$ GC-TOFMS TEQ results (ng WHO TEQ kg ${ }^{-1}$ ).

d Spike TEF: calculated (ng WHO TEQ kg ${ }^{-1}$ ).

The collaborative project with North West University (NWU), Potchefstroom, South Africa, consists of numerous soil and sediment samples taken from various strategic sites in South Africa. The samples contain various POPs, including aliphatic and aromatic hydrocarbons, polycyclic aromatic hydrocarbons (PAHs), PCBs and PCDD/Fs (detailed results to be reported in a later paper). Preliminary results indicate that the PCDD/F levels obtained for the soil and sediment samples are not much above $10 \mathrm{ng} \mathrm{TEQ} / \mathrm{kg}$. Of the more than 68 samples collected, only 14 samples indicated the presence of PDCC/Fs. The highest result obtained was $76 \mathrm{ng} \mathrm{TEQ} / \mathrm{kg}$ for $1,2,3,7,8$-PeCDD. These environmental samples are an indication of the levels of contamination to be expected in and around South Africa, emphasizing the need to make accurate measurements for these highly toxic contaminants in the South African environment at extremely low concentration levels.

\section{Conclusions}

GC $\times$ GC-TOFMS is a viable tool for dioxin screening and quantitation, making it suitable for environmental applications especially in cases where PCDD/F levels are greater than $1 \mathrm{ng} \mathrm{kg}^{-1}$. The technique is ideal for application in developing countries where GC-HRMS is not available, and can be used to minimise costs by selecting only positive samples for further overseas analysis by GC-HRMS.

The Rtx-XLB/Rtx-200 column combination provides excellent separation of the compounds mandated for analysis by US EPA Method 1613. Using a multi-step temperature program (Table 1) all seventeen PCDD and PCDF components mandated by EPA Method 1613 can be separated, even the HeCDD/F isomers, thus ensuring that the final sample TEQ value can be accurately determined as it 
is based on the individual contribution from all seventeen priority $\mathrm{PCDD} / \mathrm{F}$ isomers. Initial isomer selectivity studies for the tetrachlorinated species indicate that the method adequately separates less toxic interferents in this region.

The ChromaTOF software provides many useful features for dioxin analysis and the method has been tested on several real samples. In the case where GC-HRMS results were available, a comparison of results between the two analytical approaches revealed good agreement.

GC $\times$ GC-TOFMS additionally provides full range mass spectra for all sample components, thus allowing for identification of nontarget analytes which may be of importance, and also subsequent revisiting of archived data for detection of other compounds of concern, e.g., the brominated dioxins. It also provides additional certainty of identification by the second characteristic retention time for each target compound.

\section{Acknowledgements}

The authors express their gratitude to:

Mr Jack Cochran, Restek Corporation, 110 Benner Circle, Bellefonte, PA, USA.

Prof Jean-François Focant, Mass Spectrometry Laboratory, Biological and Organic Analytical Chemistry, University of Liège, Allée du 6 août, B6c, B-4000 Liège (Sart-Tilman), Belgium.

Dr Jui-Hwa Peng and Mr Chung-Ping Wu, Organic and Ultratrace Testing Division, Environmental Protection Agency (EPA), Taiwan.

Prof Henk Bouwman, Dr Rialet Pieters, Laura Quinn and Claudine Roos, School of Environmental Sciences and Development, Zoology, North-West University (NWU), Potchefstroom Campus, South Africa.

\section{Appendix A. Supplementary data}

Supplementary data associated with this article can be found, in the online version, at doi:10.1016/j.chroma.2011.03.050.

\section{References}

[1] P. Korytár, Comprehensive two-dimensional gas chromatography with selective detection for the trace analysis of organohalogenated contaminants. Ph.D. Thesis. Vrije Universiteit, Amsterdam, The Netherlands, 2006.

[2] S. Batterman, C. Chernyak, Y. Gouden, J. Hayes, T. Robins, S. Chetty, Environ. Pollut. 157 (2) (2009) 654.

[3] C.W. Davy, Environ. Int. 30 (2) (2004) 219.

[4] L.S. Birnbaum, M.J. de Vito, Toxicology 105 (1995) 391.

[5] J.-F. Focant, C. Pirard, G. Eppe, E. de Pauw, J. Chromatogr. A 1067 (2004) 265.

[6] J. de vos, R. Dixon, G. Vermeulen, P. Gorst-Allman, J. Cochran, E. Rohwer, J.-F. Focant, Chemosphere 82 (2011) 1230.

[7] US Environmental Protection Agency, Method 1613, Tetra through Octachlorinated Dioxins and Furans by Isotopic Dilution HRGC-HRMS, 1994.

[8] J-M.D. Dimandja, G.C. Clouden, I. Colón, J.-F. Focant, W.V. Cabey, R.C. Parry, J. Chromatogr. A 1019 (2003) 261.

[9] G.Semard, M. Adahchour, J.-F. Focant, Wilson and Wilson's comprehensive analytical chemistry, in: Comprehensive Two Dimensional Gas Chromatography, vol. 55, Elsevier, Oxford, 2009.

[10] J.-F. Focant, E.J. Reiner, K. Macpherson, T. Kolic, A. Sjödin, D.G. Patterson Jr., S.L. Reese, F.L. Dorman, J.W. Cochran, Talanta 63 (2004) 1231

[11] J.-F. Focant, A. Sjödin, D.G. Patterson Jr., J. Chromatogr. A 1040 (2004) 227.

[12] G. Eppe, J.-F. Focant, C. Pirard, E. De Pauw, Talanta 63 (5) (2004) 1135.

[13] E.J. Reiner, R.E. Clement, A.B. Okey, C.H. Marvin, Anal. Bioanal. Chem. 386 (4) (2006) 791

[14] J.-F. Focant, G. Eppe, M.-L. Scippo, A.C. Massart, C. Pirard, G. Maghuin-Rogister, E. De Pauw, J. Chromatogr. A 1086 (2005) 45.

[15] US Environmental Protection Agency, Method 3545, Pressurized Fluid Extraction (PFE), 1996.

[16] US Environmental Protection Agency, Method 3620c, Florisil Cleanup, 2007.

[17] US Environmental Protection Agency, Method 3600c, Cleanup, 1996.

[18] J.-F. Focant, G. Eppe, C. Pirard, E. De Pauw, J. Chromatogr. A 925 (2001) 207.

[19] J.-F. Focant, E. De Pauw, J. Chromatogr. B 776 (2002) 199.

[20] F.L. Dorman, E.B. Overton, J.J. Whiting, J.W. Cochran, J. Gardea-Torresdey, Anal. Chem. 80 (12) (2008) 4487.

[21] E. Hoh, K. Mastovska, S.J. Lehotay, J. Chromatogr. A 1145 (2007) 210.

[22] P. Schoenmakers, P. Marriott, J. Beens, LC-GC (2003).

[23] M. van den Berg, L.S. Birnbaum, M. Denison, M. De Vito, W. Farland, M. Feeley, H. Fiedler, H. Hakansson, A. Hanberg, L. Haws, M. Rose, S. Safe, D. Schrenk, C. Tohyama, A. Tritscher, J. Tuomisto, M. Tysklind, N. Walker, R.E. Peterson, J. Toxicol. Sci. 93 (2) (2006) 223.

[24] US Environmental Protection Agency, Method 8290A, Polychlorinated Dibenzo-p-Dioxins (PCDDs) and Polychlorinated Dibenzofurans (PCDFs) by High Resolution Gas Chromatography/ High Resolution Mass Spectrometry (HRGC/HRMS), 2007.

[25] M. Pereira de Souza, Quim. Nova 27 (6) (2004) 934.

[26] A. Schecter, L. Birnbaum, J.J. Ryan, J.D. Constable, Environ. Res. 101 (2006) 419. 
Supporting Information

Table 1a.GCxGC Column combinations evaluated

\begin{tabular}{cll}
\hline & Primary column & Secondary column \\
\hline 1 & Rtx-Dioxin 2 & Rtx-PCB \\
& $(60 \mathrm{~m} \times 0.25 \mathrm{~mm}$ id $\times 0.25 \mu \mathrm{m} \mathrm{df})$ & $(2.0 \mathrm{~m} \times 0.18 \mathrm{~mm}$ id $\times 0.18 \mu \mathrm{m} \mathrm{df})$ \\
2 & Rxi-5SilMS & Rtx-200 \\
& $(30 \mathrm{~m} \times 0.25 \mathrm{~mm}$ id $\times 0.25 \mu \mathrm{m} \mathrm{df})$ & $(2.0 \mathrm{~m} \times 0.18 \mathrm{~mm}$ id $\times 0.18 \mu \mathrm{m} \mathrm{df})$ \\
3 & Rtx-XLB & Rtx-200 \\
& $(30 \mathrm{~m} \times 0.25 \mathrm{~mm}$ id $\times 0.25 \mu \mathrm{m} \mathrm{df})$ & $(2.0 \mathrm{~m} \times 0.18 \mathrm{~mm}$ id $\times 0.20 \mu \mathrm{m} \mathrm{df})$ \\
\hline
\end{tabular}


Table 1b.GCxGC-TOFMS parameters (method based on Hoh et al)

\begin{tabular}{|c|c|}
\hline First dimension column & Rtx-Dioxin2 (60 $\mathrm{m} \times 0.25 \mathrm{~mm}$ id $\times 0.25 \mu \mathrm{m}$ df) \\
\hline Second dimension column & Rtx-PCB $(2.0 \mathrm{~m} \times 0.18 \mathrm{~mm}$ id $\times 0.20 \mu \mathrm{m} \mathrm{df})$ \\
\hline Carrier gas & Helium \\
\hline Injection mode & Splitless \\
\hline Injection volume & $2 \mu l$ \\
\hline Solvent & Iso-octane \\
\hline Flow mode & Corrected constant flow via pressure ramps \\
\hline Flow rate & $\begin{array}{l}2.0 \mathrm{ml}^{\mathrm{min}} \mathrm{m}^{-1} \text { for } 40 \mathrm{~min} \text {, then at } 2.5 \mathrm{ml} \cdot \mathrm{min}^{-1}(0.5 \\
\mathrm{ml} \cdot \mathrm{min}^{-1} \text { ramp rate) to end of run }\end{array}$ \\
\hline Total analysis time & $59.83 \mathrm{~min}$ \\
\hline Inlet purge time & $60 \mathrm{~s}$ \\
\hline Inlet purge flow & $40 \mathrm{ml} \cdot \mathrm{min}^{-1}$ \\
\hline Inlet total flow & $42 \mathrm{ml} \cdot \mathrm{min}^{-1}$ \\
\hline Inlet temperature & $275^{\circ} \mathrm{C}$ \\
\hline Oven equilibration time & $1 \mathrm{~min}$ \\
\hline${ }^{1} \mathrm{D}$ column temperatures & $\begin{array}{l}140{ }^{\circ} \mathrm{C} \text { for } 1 \mathrm{~min} \text {, ramp at } 30^{\circ} \mathrm{C} \cdot \mathrm{min}^{-1} \text { to } 180^{\circ} \mathrm{C} \text {, no } \\
\text { hold, then at } 2{ }^{\circ} \mathrm{C} \cdot \mathrm{min}^{-1} \text { to } 250^{\circ} \mathrm{C} \text {, then at } 20^{\circ} \mathrm{C} \cdot \mathrm{min}^{-1} \\
\text { to } 300^{\circ} \mathrm{C} \text {, hold for } 20 \mathrm{~min}\end{array}$ \\
\hline${ }^{2} \mathrm{D}$ column temperatures & $\begin{array}{l}160{ }^{\circ} \mathrm{C} \text { for } 1 \mathrm{~min} \text {, ramp at }{ }^{\circ} \mathrm{C} \cdot \mathrm{min}^{-1} \text { to } 200{ }^{\circ} \mathrm{C} \text {, no } \\
\text { hold, then at } 2{ }^{\circ} \mathrm{C} \cdot \mathrm{min}^{-1} \text { to } 270^{\circ} \mathrm{C} \text {, then at } 20^{\circ} \mathrm{C} \cdot \mathrm{min}^{-1} \\
\text { to } 320^{\circ} \mathrm{C} \text {, hold for } 20 \mathrm{~min}\end{array}$ \\
\hline Transfer line temperature & $270^{\circ} \mathrm{C}$ \\
\hline Modulator temperature offset & $35^{\circ} \mathrm{C}$ \\
\hline Modulation period & $3 \mathrm{~s}$ \\
\hline Hot pulse time & $0.8 \mathrm{~s}$ \\
\hline Cool time between stages & $0.7 \mathrm{~s}$ \\
\hline Acquisition delay & $600 \mathrm{~s}$ \\
\hline Start mass & $160 \mathrm{u}$ \\
\hline End mass & $520 \mathrm{u}$ \\
\hline Acquisition rate & 50 spectra/ s \\
\hline Detector voltage & $1850 \mathrm{~V}$ \\
\hline Electron energy & $-80 V$ \\
\hline Mass defect setting & $-40 \mathrm{mu} / 100 \mathrm{u}$ \\
\hline Ion source temperature & $250^{\circ} \mathrm{C}$ \\
\hline
\end{tabular}


Table 1c.GCxGC-TOFMS parameters (Taiwan EPA data)

\begin{tabular}{|c|c|}
\hline First dimension column & Rxi-5Sil MS (30 $\mathrm{m} \times 0.25 \mathrm{~mm}$ id $\times 0.25 \mu \mathrm{m} d f)$ \\
\hline Second dimension column & Rtx-200 (1.5 m x $0.18 \mathrm{~mm}$ id $\times 0.20 \mu \mathrm{m}$ df $)$ \\
\hline Carrier gas & Helium \\
\hline Injection mode & Splitless \\
\hline Injection volume & $2 \mu \mathrm{l}$ \\
\hline Solvent & Iso-octane \\
\hline Flow mode & Constant flow \\
\hline Flow rate & $1.5 \mathrm{ml} \cdot \mathrm{min}^{-1}$ \\
\hline Total analysis time & $40 \mathrm{~min}$ \\
\hline Inlet purge time & $60 \mathrm{~s}$ \\
\hline Inlet purge flow & $40 \mathrm{ml} \cdot \mathrm{min}^{-1}$ \\
\hline Inlet total flow & $41 \mathrm{ml} \cdot \mathrm{min}^{-1}$ \\
\hline Inlet temperature & $250^{\circ} \mathrm{C}$ \\
\hline Oven equilibration time & $0.5 \min$ \\
\hline${ }^{1} \mathrm{D}$ column temperatures & $\begin{array}{l}80{ }^{\circ} \mathrm{C} \text { for } 1 \mathrm{~min} \text {, ramp at } 20^{\circ} \mathrm{C} \cdot \mathrm{min}^{-1} \text { to } 220^{\circ} \mathrm{C} \text {, no } \\
\text { hold, at } 2{ }^{\circ} \mathrm{C} \cdot \mathrm{min}^{-1} \text { to } 240{ }^{\circ} \mathrm{C} \text {, no hold, at } 1^{\circ} \mathrm{C} \cdot \mathrm{min}^{-1} \text { to } \\
250^{\circ} \mathrm{C} \text {, no hold, at } 5^{\circ} \mathrm{C} \cdot \mathrm{min}^{-1} \text { to } 260^{\circ} \mathrm{C} \text {, no hold, at } \\
1^{\circ} \mathrm{C} \cdot \mathrm{min}^{-1} \text { to } 270{ }^{\circ} \mathrm{C} \text {, no hold }\end{array}$ \\
\hline${ }^{2} \mathrm{D}$ column temperatures & $\begin{array}{l}90{ }^{\circ} \mathrm{C} \text { for } 1 \mathrm{~min} \text {, ramp at } 20^{\circ} \mathrm{C} \cdot \mathrm{min}^{-1} \text { to } 230{ }^{\circ} \mathrm{C} \text {, no } \\
\text { hold, at } 2^{\circ} \mathrm{C} \cdot \mathrm{min}^{-1} \text { to } 250^{\circ} \mathrm{C} \text {, no hold, at } 1^{\circ} \mathrm{C} \cdot \mathrm{min}^{-1} \text { to } \\
260{ }^{\circ} \mathrm{C} \text {, no hold, at } 5^{\circ} \mathrm{C} \cdot \mathrm{min}^{-1} \text { to } 270^{\circ} \mathrm{C} \text {, no hold, at } 1 \\
{ }^{\circ} \mathrm{C} \cdot \mathrm{min}^{-1} \text { to } 280^{\circ} \mathrm{C} \text {, no hold }\end{array}$ \\
\hline Transfer line temperature & $270^{\circ} \mathrm{C}$ \\
\hline Modulator temperature offset & $30^{\circ} \mathrm{C}$ \\
\hline Modulation period & $4 \mathrm{~s}$ \\
\hline Hot pulse time & $1.0 \mathrm{~s}$ \\
\hline Cool time between stages & $1.0 \mathrm{~s}$ \\
\hline Acquisition delay & $900 \mathrm{~s}$ \\
\hline Start mass & $60 u$ \\
\hline End mass & $500 u$ \\
\hline Acquisition rate & 50 spectra/ s \\
\hline Detector voltage & $1900 \mathrm{~V}$ \\
\hline Electron energy & $-70 \mathrm{~V}$ \\
\hline Mass defect setting & $-40 \mathrm{mu} / 100 \mathrm{u}$ \\
\hline Ion source temperature & $250^{\circ} \mathrm{C}$ \\
\hline
\end{tabular}


Table 1d. GC-TOFMS parameters (adapted from the standard solution assayparameters for EDF-4147 PCDD/F isomer specificity mix)

\begin{tabular}{|c|c|}
\hline First dimension column & Rxi-5 Sil MS (30 $\mathrm{m} \times 0.25 \mathrm{~mm}$ id $\times 0.25 \mu \mathrm{m}$ df) \\
\hline Second dimension column & Rtx-200 (1.5 m x $0.18 \mathrm{~mm}$ id $\times 0.20 \mu \mathrm{m}$ df $)$ \\
\hline Carrier gas & Helium \\
\hline Injection mode & Splitless (adapted cooled-on-column) \\
\hline Injection volume & $1 \mu \mathrm{l}$ \\
\hline Solvent & Iso-octane \\
\hline Flow mode & Constant flow \\
\hline Flow rate & $1.5 \mathrm{ml} \cdot \mathrm{min}^{-1}$ (was not specified) \\
\hline Total analysis time & $26.7 \mathrm{~min}$ \\
\hline Inlet purge time & $60 \mathrm{~s}$ \\
\hline Inlet purge flow & $40 \mathrm{ml} \cdot \mathrm{min}^{-1}$ \\
\hline Inlet total flow & $41 \mathrm{ml} \cdot \mathrm{min}^{-1}$ \\
\hline Inlet temperature & $250^{\circ} \mathrm{C}$ \\
\hline Oven equilibration time & $0.5 \mathrm{~min}$ \\
\hline${ }^{1} \mathrm{D}$ column temperatures & $\begin{array}{l}140^{\circ} \mathrm{Cfor} 0.2 \mathrm{~min} \text {, at } 40^{\circ} \mathrm{C} \cdot \mathrm{min}^{-1} \text { to } 200^{\circ} \mathrm{C} \text {, at } 4^{\circ} \mathrm{C} \cdot \mathrm{min}^{-} \\
{ }^{1} \text { to } 300^{\circ} \mathrm{C} \text {, no hold }\end{array}$ \\
\hline${ }^{2} \mathrm{D}$ column temperatures & $\begin{array}{l}145^{\circ} \mathrm{C} \text { for } 0.2 \mathrm{~min} \text {, at } 40^{\circ} \mathrm{C} \cdot \mathrm{min}^{-1} \text { to } 205^{\circ} \mathrm{C} \text {, at } 4^{\circ} \mathrm{C} \text {. } \\
\min ^{-1} \text { to } 305^{\circ} \mathrm{C} \text {, no hold }\end{array}$ \\
\hline Transfer line temperature & $270^{\circ} \mathrm{C}$ \\
\hline Modulator temperature offset & $30^{\circ} \mathrm{C}$ \\
\hline Modulation period & $0 \mathrm{~s}\left({ }^{1} \mathrm{D}\right.$ method $)$ \\
\hline Hot pulse time & $1.0 \mathrm{~s}$ \\
\hline Cool time between stages & $1.0 \mathrm{~s}$ \\
\hline Acquisition delay & $900 \mathrm{~s}$ \\
\hline Start mass & $200 u$ \\
\hline End mass & $520 \mathrm{u}$ \\
\hline Acquisition rate & 10 spectra/s \\
\hline Detector voltage & $1850 \mathrm{~V}$ \\
\hline Electron energy & $-70 \mathrm{~V}$ \\
\hline Mass defect setting & $-40 \mathrm{mu} / 100 \mathrm{u}$ \\
\hline Ion source temperature & $250^{\circ} \mathrm{C}$ \\
\hline
\end{tabular}


Table 5.Retention times for the PCDD/Fs using the Rxi-5 Sil MS/ Rtx-200 (Taiwan EPA results, Table 2) and Rxi-XLB/ Rtx-200 (SA sample spike recovery results, Table 4) column combinations.

\begin{tabular}{l|c|c|c|c}
\hline \multicolumn{1}{c|}{ Compound } & \multicolumn{2}{c|}{ Rxi-5 Sil MS/ Rtx-200 } & \multicolumn{2}{c}{ Rxi-XLB/ Rtx-200 } \\
\hline $2,3,7,8-T C D F$ & ${ }^{1}$ D RT & ${ }^{2}$ D RT & ${ }^{1}$ D RT & ${ }^{2}$ D RT \\
$2,3,7,8-T C D D$ & 944 & 2.16 & 1088 & 1.76 \\
$1,2,3,7,8-P e C D F$ & 972 & 2.16 & 1116 & 1.76 \\
$2,3,4,7,8-P e C D F$ & 1136 & 2.50 & 1332 & 2.02 \\
$1,2,3,7,8-P e C D D$ & 1192 & 2.66 & 1420 & 2.16 \\
$1,2,3,4,7,8-H x C D F$ & 1212 & 2.12 & 1436 & 2.12 \\
$1,2,3,6,7,8-H x C D F$ & 1416 & 3.00 & 1720 & 2.34 \\
$2,3,4,6,7,8-H x C D F$ & 1428 & 3.02 & 1732 & 2.38 \\
$1,2,3,4,7,8-H x C D D$ & 1480 & 3.34 & 1800 & 2.62 \\
$1,2,3,6,7,8-H x C D D$ & 1500 & 3.18 & 1812 & 2.5 \\
$1,2,3,7,8,9-H x C D D$ & 1512 & 3.20 & 1824 & 2.52 \\
$1,2,3,7,8,9-H x C D F$ & 1536 & 3.34 & 1848 & 2.62 \\
$1,2,3,4,6,7,8-H p C D F$ & 1564 & 3.40 & 1888 & 2.68 \\
$1,2,3,4,6,7,8-H p C D D$ & 1740 & 3.20 & 2064 & 2.72 \\
$1,2,3,4,7,8,9-H p C D F$ & 1860 & 3.22 & 2216 & 2.9 \\
OCDD & 1908 & 3.28 & 2296 & 2.92 \\
OCDF & 2212 & 3.72 & 2616 & 3.16 \\
\hline
\end{tabular}


Figure 5a. Ion profiles for the native and labeled 2,3,7,8-TCDD (sample spike)

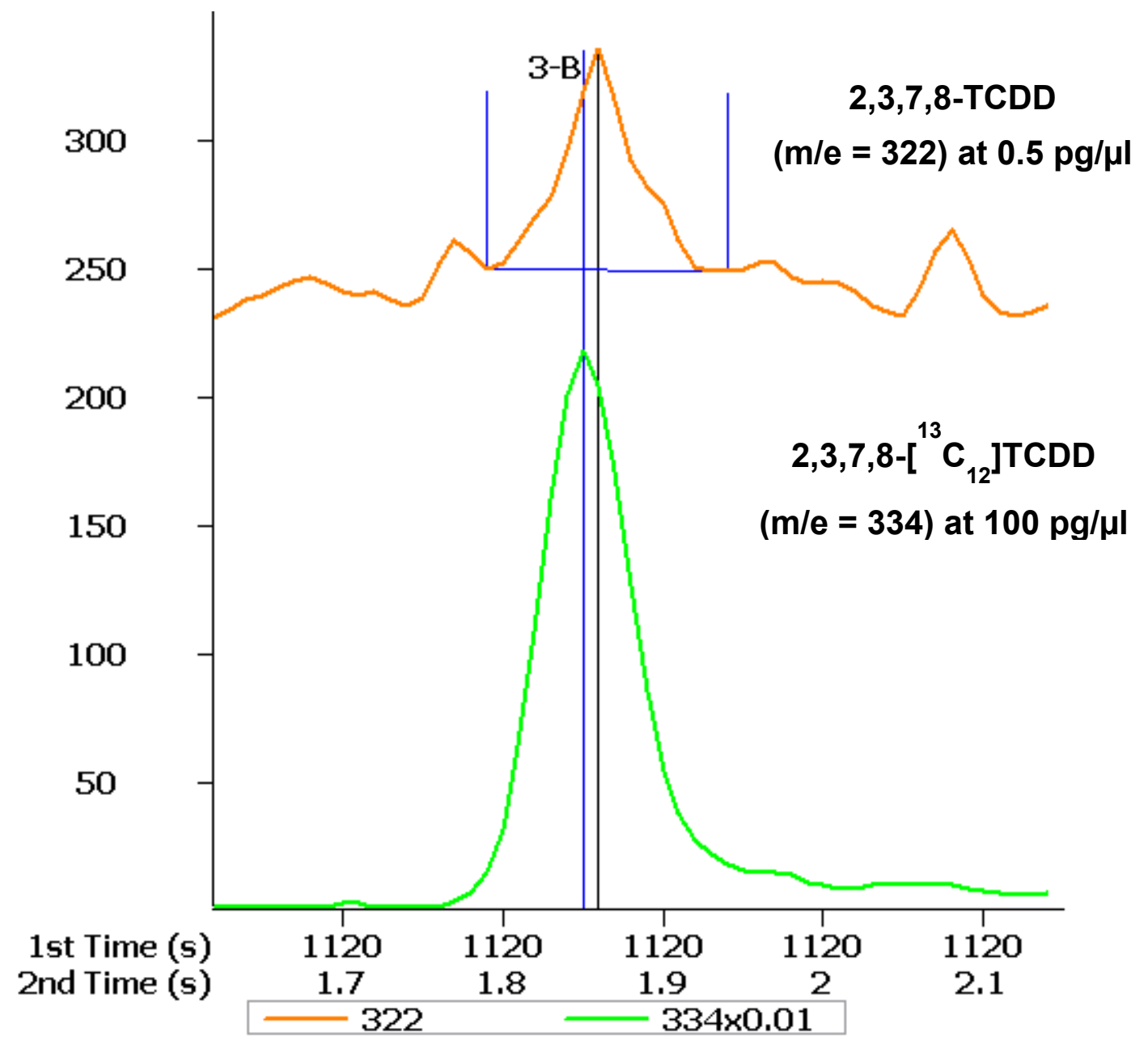


Figure 5b.The lowest calibration standard (CS1) has an instrument $\mathrm{S} / \mathrm{N}$ given as 97. Measured manually, the $\mathrm{S} / \mathrm{N}$ is $\sim 20$ (Figure EPA 8290a Manual Determination of $S / N$, Figure 6)

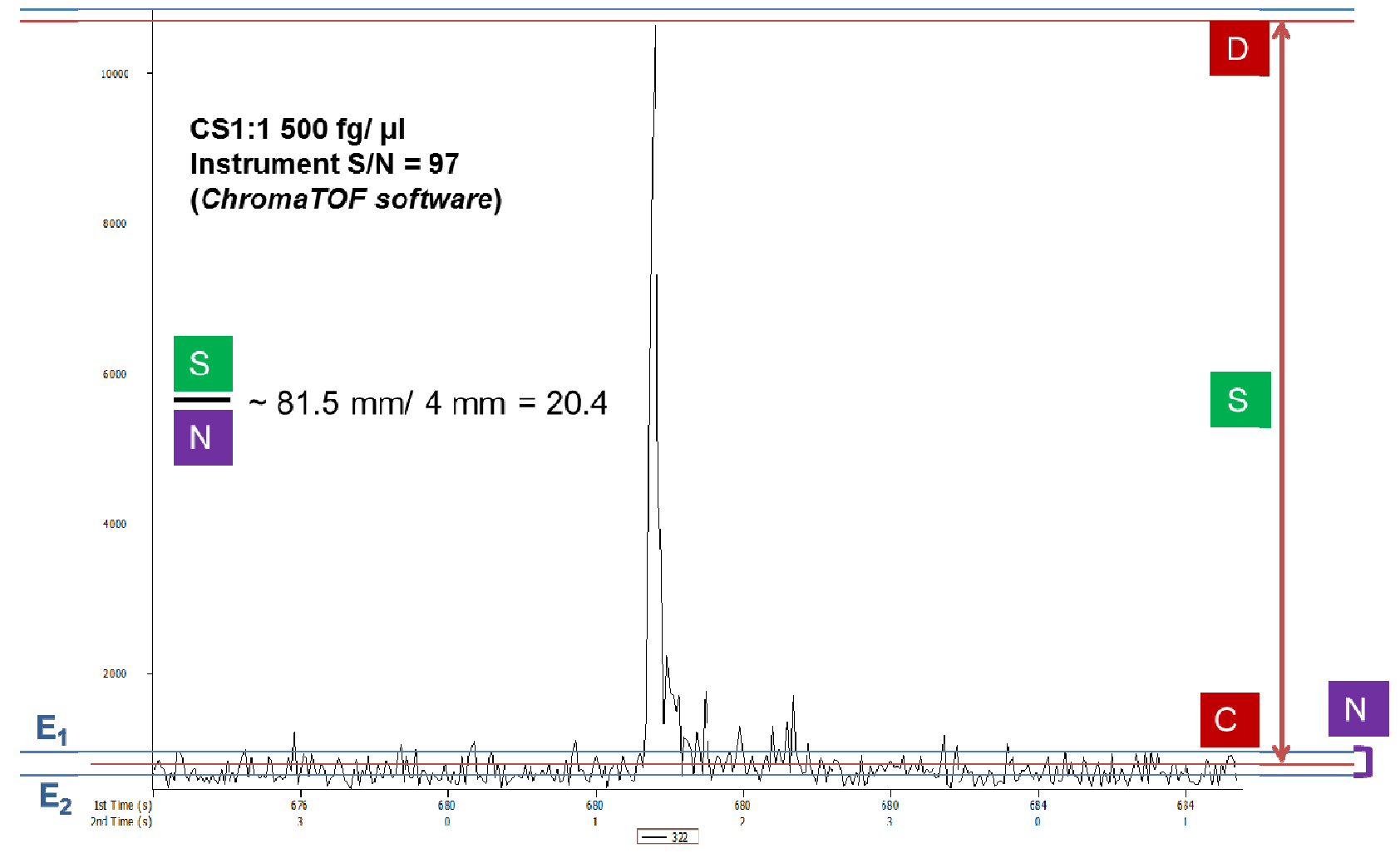


Figure 5c.The mass spectrum obtained for lowest calibration standard (CS1) showing the $\mathrm{m} / \mathrm{z}=306$ for2,3,7,8-TCDF. The PCDF congeners were compared against a user library created for PCDD/Fs
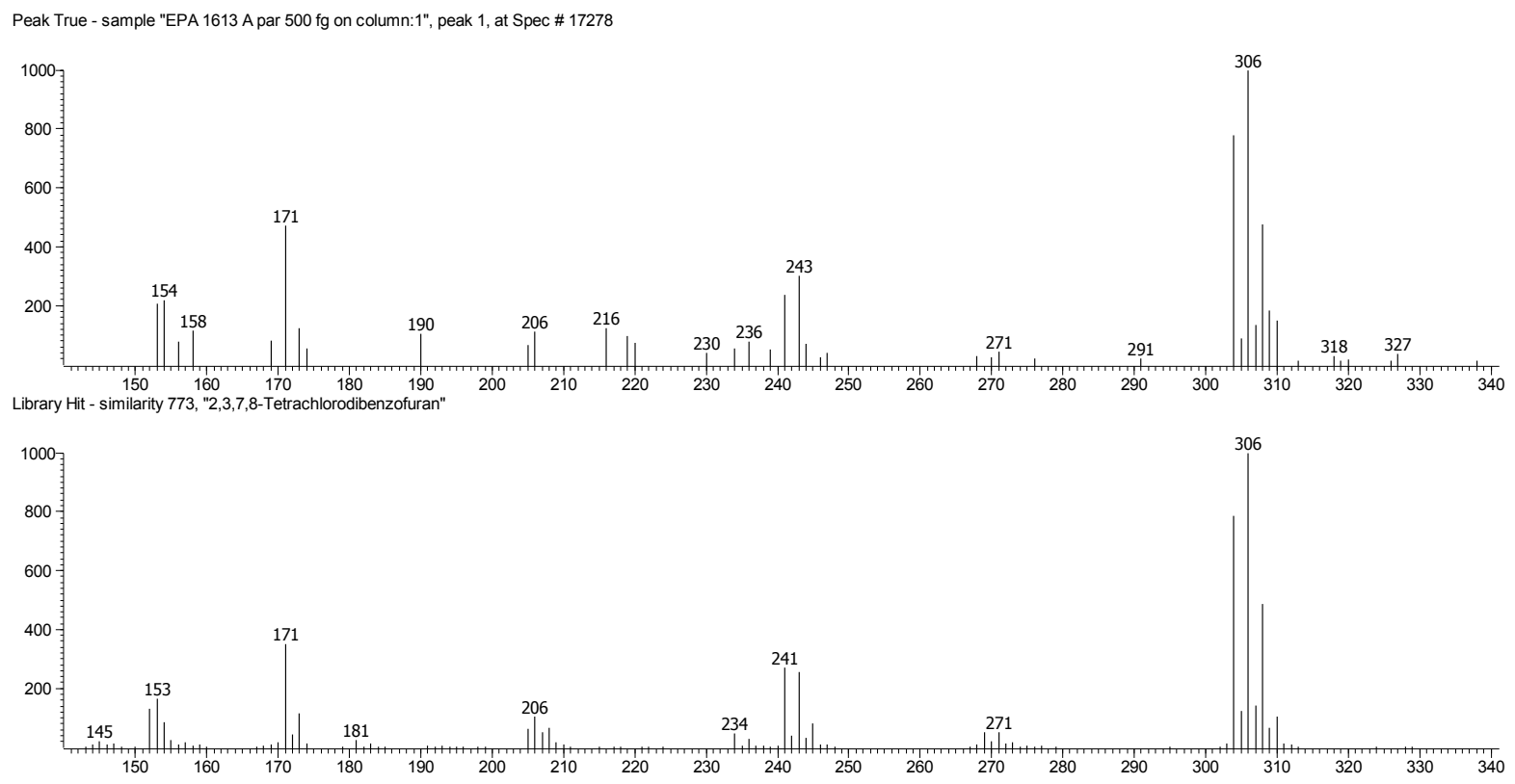

Figure 5d.The mass spectrum obtained for lowest calibration standard (CS1) showing the $\mathrm{m} / \mathrm{z}=322$ for 2,3,7,8-TCDD. The PCDD congeners were compared against a user library created for PCDD/Fs
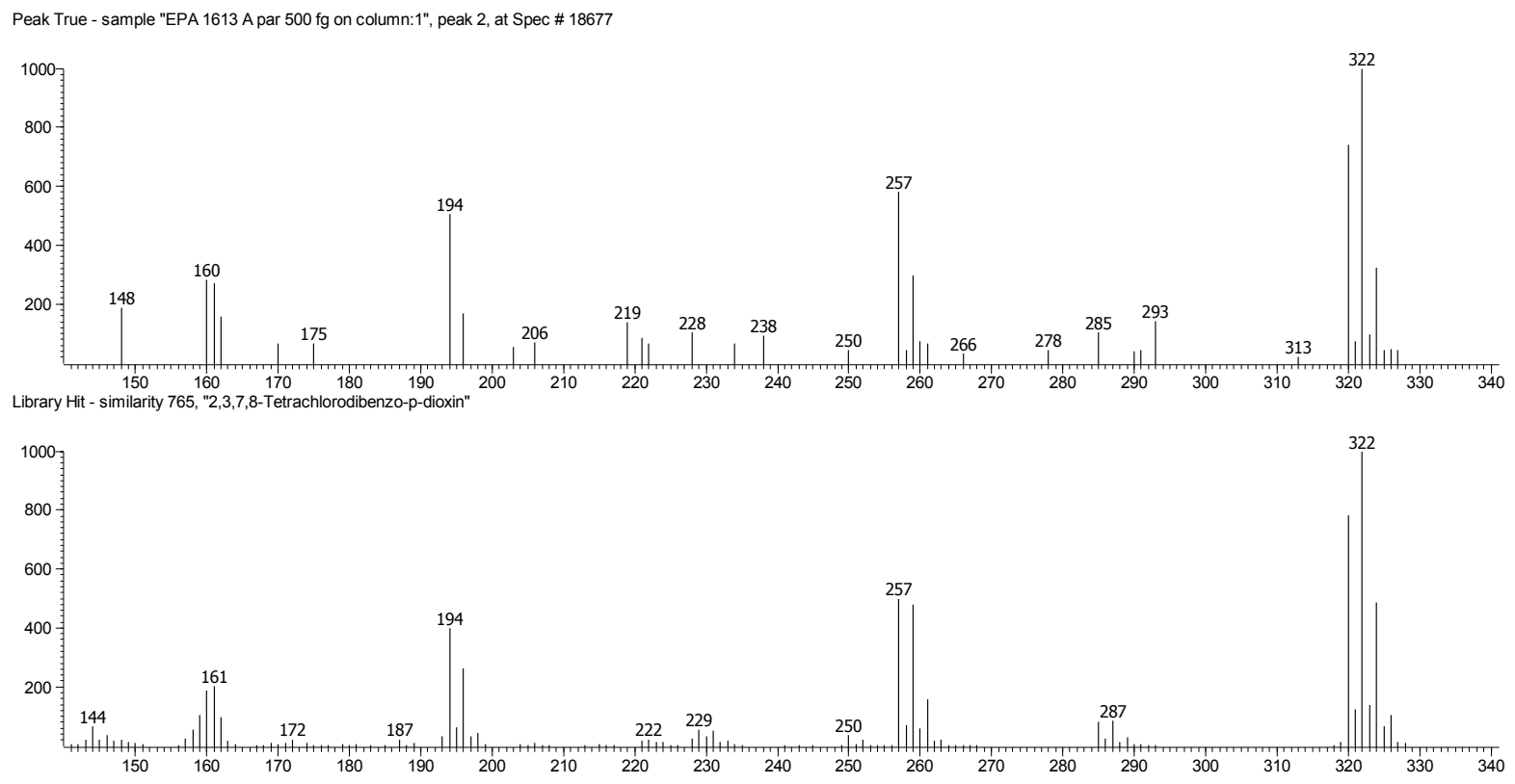